\title{
自然演繹に基づく論理推論の文間類似度学習・ 含意関係認識への応用
}

\author{
谷中 瞳
}

文と文がどのような意味的関係にあるかという文間の関連性の計算は, 情報検索や 文書分類, 質問応答などの自然言語処理の基盤を築く重要な技術である. 文の意味 をべクトルや数值で表現する手法は未だ発展途上であり, 自然言語処理分野におい ては，様々な機械学習による手法が活発に研究されている。これらの手法では，文 字や単語を単位としたべクトルを入力として, それらの表層的な出現パターンとそ の振る舞いを学習することで, 文べクトルを獲得している。しかし, 否定表現を含 む文など, 文の構造的意味を正確に表現できるかは自明ではない，一方で, 形式意 味論においては, 表現力の高い高階論理に基づいて意味の分析を行う研究が発展し ているが, 文間の関連性のような, 連続的な意味的関係を表現することが困難であ る. そこで本研究では, 機械学習と論理推論という二つの手法を組み合わせて文間 の関連性を計算する手法を提案する。具体的には, 文間の含意関係を高階論理の推 論によって判定するシステムの実行過程から, 文間の関連性に寄与する特徵を抽出 し, 文間の関連性を学習する。文間類似度学習と含意関係認識という 2 つの自然言 語処理タスクに関して提案手法の評価を行った結果, 推論の過程に関する情報を特 徵量に用いることによって，いずれのタスクにおいても精度が向上した。また，含 意関係認識用データセットの一つである SICK データセットの評価では, 最高精度 を達成した。

キーワード：文間類似度，含意関倸認識，自然演繹，論理推論

\section{Learning Semantic Textual Relatedness using Natural Deduction Proofs}

\author{
Hitomi Yanaka ${ }^{\dagger}$, Koji Mineshima ${ }^{\dagger \dagger}$, Pascual Martínez-Gómez ${ }^{\dagger \dagger}$ and \\ DAISUKE BEKKI ${ }^{\dagger \dagger}$
}

Learning semantic textual relatedness is a core research subject in natural language processing. Vector-based models are often used to compute sentence representations from words or predicate-argument structures, but these models cannot capture semantics accurately with consistency. Conversely, logical semantic representations can capture sentence semantics in depth and with much greater accuracy, but their symbolic

\footnotetext{
†東京大学, The University of Tokyo

†† お茶の水女子大学, Ochanomizu University

††産業技術総合研究所, National Institute of Advanced Industrial Science and Technology
} 
nature does not offer graded notions of textual similarity. We propose a method for learning semantic textual relatedness by combining shallow features with features extracted from natural deduction proofs using bidirectional entailment relations between sentence pairs. For the natural deduction proofs, we use ccg2lambda, a higher-order automatic inference system that converts Combinatory Categorial Grammar (CCG) derivation trees into semantic representations and conducts natural deduction proofs. We evaluate our system using two major NLP tasks: learning textual similarity and recognizing textual entailment. Our experiments demonstrate that our approach can outperform other logic-based systems and we obtain high performance levels for the RTE task using the SICK dataset. Our evaluations also demonstrate that features derived from the proofs are effective for learning semantic textual relatedness and we quantify our contribution to the research area.

Key Words: Semantic Textual Similarity, Recognizing Textual Entailment, Predicate Logic, Inference, Natural Deduction

\section{1 はじめに}

ある二つの文について，それぞれの文がどのような意味を持ち，一方の文と他方の文とがど のような意味的関係にあるかという文間の関連性の評価は，情報検索や文書分類，質問応答な どの自然言語処理の基盤を築く重要な技術である。これまでの自然言語処理における文の意味 表現の方法は，ベクトル空間モデルが主流である。情報検索においては，単語や文字の出現頻 度といった表層的な情報を用いて, 統計的機械学習に基づいて文ベクトルを導出する手法が用 いられてきた。 また，さらに正確な文の意味表現を目指して，単語やフレーズといった構成要 素を組み合わせて文の意味を計算するベクトル空間モデル (Wong and Raghavan 1984; Mitchell and Lapata 2010; Le and Mikolov 2014) が提案されてきた. 近年では, 深層学習を用いて高精度 で文の意味表現を獲得する手法 (Mueller and Thyagarajan 2016; Hill, Cho, and Korhonen 2016) が多く提案されている。これらの手法では，単語ベクトルや文字ベクトルを入力として学習を 行い, 文べクトルを獲得しているが, 獲得した文べクトルが否定表現や数量表現などを含む文の 意味を正確に表現しているかは自明ではない.たとえば, Tom did not meet some of the players と Tom did not meet any of the players という文はほとんど単語が共通しており， someや any といった機能語は通常捨象されるか, ほほ同じ単語ベクトルとして扱われる。しかし，前者は $\Gamma T o m$ は選手の何人かとは会わなかった（別の何人かの選手とは会った）」，後者は「Tom はど の選手とも会わなかった」という意味を表しており，これらの文の意味の違いを単語や文字か らの情報を用いてどのようにして捉えるかが課題となっている。そこで，統語構造を考慮した モデルなど，より高度な意味解析を取り入れたモデルの構築が期待されている.

一方で, 文の意味を論理式で表現し，論理推論によって高度な意味解析を行う手法 (Mineshima, 
Martínez-Gómez, Miyao, and Bekki 2015; Mineshima, Tanaka, Martínez-Gómez, Miyao, and Bekki 2016; Abzianidze 2015, 2016) は，論理式による意味表現と整合性の高い組合せ範疇文法 (Combinatory Categorial Grammar, CCG) (Steedman 2000)による頑健な統語解析の発展に伴 い，近年研究が進められている。論理推論を用いた手法は，文ぺアに対して一方の文を他方の 文が内容的に含意しているかどうかを判定する含意関係認識の夕スクで高精度を達成しており, 様々な自然言語処理タスクへの応用が期待されている。一方で，論理推論を用いた手法は元来 厳密な手法であり，部分的・段階的な含意関係や類似関係を扱うことが困難である.

そこで本研究では，機械学習と論理推論とを組み合わせることで，柔軟かつ正確に文の関連 性を学習する方法を検討する。具体的には, 文の意味を論理式で表現し，2文間の双方向の含 意関係について自然演繹による推論を試み, 推論の過程と結果を抽出する。このとき, 必要に 応じて，文間の意味的関係を正しく判定するために必要な語彙知識を公理として追加して推論 を試みる。語彙知識の利用によって文間の意味的関係が判定できれば，純粋な論理推論だけで は意味的関係を判定できない文ぺアにおいても，部分的な推論過程から文の関連性を示す情報 を抽出することが可能となる。抽出した推論の過程と結果に関する情報を用いて，文の関連性 を学習する。

\section{2 関連研究}

文の意味表現を獲得し，文の関連性を学習する手法はこれまでに幅広く研究されている. 特 に，文の意味は文を構成する部分の意味から合成されるという構成性の原理に基づいて，単語べ クトルの加法と乗法を用いて文の意味を表現する手法 (Mitchell and Lapata 2008, 2010) が提案 された。 しかし, この手法には, 単語の出現順序が捨象されてしまうという問題があった。 そこ で，述語や機能語を高階テンソル，名詞をベクトルで表現し，縮約を用いて文の意味を計算する Categorical Compositional Distributional Semantic Model (Clark, Coecke, and Sadrzadeh 2011; Grefenstette and Sadrzadeh 2011; Kartsaklis, Kalchbrenner, and Sadrzadeh 2014; Kartsaklis and Sadrzadeh 2016) が提案されている。しかし，これらの手法では比較的単純な構造の文のみを対 象としており，否定や条件などの機能的な表現をどのように扱いうるかは明らかではない.

近年では，深層学習の手法を用いた文の意味表現に関する研究が活発に進められている。文 間類似度学習タスクでは，単語ベクトルと類義語ベクトルから双方向型 LSTM を用いて文の意 味表現を学習するモデル (Mueller and Thyagarajan 2016) が提案されており，最高精度を記録 している。また，構文木に沿って文の意味表現を再帰的に構築する Tree-LSTM を用いたモデ ル (Tai, Socher, and Manning 2015; Zhou, Liu, and Pan 2016) や, LSTM を用いて文脈全体の意 味を学習したのちに，CNNを用いて各文の局所的な特徵を学習するモデル (He and Lin 2016) など，より文の構造を考慮した深層学習のモデルが提案されている。しかし，深層学習による 
アプローチは大量の文を入力として end-to-end で文の意味表現を学習するため, 内容語と機能 語の意味をどのように区別して扱っているのかは明らかではない.

一方で, 論理推論によるアプローチは個々の文について意味解析を行い, 直接的に文の意味 表現（論理式）を獲得する。ここでの意味解析は理論言語学の知見に基づくものであり，内容語 と機能語の意味を区別して扱う。文を論理式に変換し，論理推論を用いて文間の意味的関係を 判定する手法には大きく分けて 2 つの手法が提案されている。1つは, 論理推論のみを用いて いわゆる教師なし学習で文間の意味的関係を判定する手法である. 具体的には, タブローを用 いた手法 (Abzianidze 2015，2016) や，自然演繹を用いた手法 (Mineshima et al. 2015, 2016) が 提案されている。これらの手法は, 文を一階述語論理式よりも表現力の高い高階述語論理式で 表現し, 効率的な自然言語推論を実現することによって, 含意関係認識のタスクで高精度を達 成している。一方で, 文間類似度の計算といった, よりソフトな推論への適用が課題となって いる.

もう 1 つの手法は, 統計的機械学習と, 論理推論とを組み合わせて, 教師あり学習で意味的 関係を判定する手法である。この手法では, 論理推論で得られた結果を機械学習や確率モデル を用いて近似することで, ソフトな推論を実現している. Bjervaらは, 分散表現から導出した 文中の単語間類似度と, 一階述語論理による推論を用いて判定した含意関係とをそれぞれ特徵 量に用いて，文間類似度や含意関係を学習する手法を提案している (Bjerva, Bos, van der Goot, and Nissim 2014) 。また, Beltagyらは, Probabilistic Soft Logicによる類似度学習方法を提案 している (Beltagy, Roller, Boleda, Erk, and Mooney 2014). Probabilistic Soft Logic では, 文を 一階述語論理式に変換し, 含意関係を満たす度合いとして単語の分散表現を用いて一方の文と 他方の文との論理式間の重みを計算する。この重みを特徵量として, 加法回帰モデルを用いて 文間類似度を予測している。これらの先行研究から, 推論による文間の含意関係の判定結果や 論理式は文の言語的な情報を良質な形式で表現しているため, 文間類似度学習に有用な情報で あることが示唆されている。しかし, 先行研究で学習に利用している推論に関する情報は, 推 論の判定結果（文間の意味的関係が含意・矛盾・不明のいずれであるか）や，2つの文において 共通する論理式の割合にとどまっており，これらは推論から得られる情報のほんの一部でしか ない.

\section{3 提案手法}

\section{1 提案手法の全体像}

本研究では文の意味を文間の含意関係に基づいて規定する証明論的意味論 (Bekki and Mineshima 2017) の観点から, 文間の双方向の含意関係の証明を介して文間の関連性を計算 する手法を提案する。一方の文と他方の文との関連が低いほど，2文間の含意関係を証明する 
にはより多くの公理生成や推論規則の適用が必要となり, 証明の過程が複雑になる。したがっ て，証明の結果だけではなく，含意関係を判定するまでの証明の実行過程も，文間の関連性の 評価に有用なはずである。一方の文を前提，他方の文を結論とみなして，前提から結論を導く 推論の手法である自然演繹 (Prawitz 1965) に基づく証明では, 証明の実行過程を分析すること が可能である。そこで提案手法では，2 文間の双方向の含意関係について自然演繹による証明 を試み，証明の実行過程から文間の関連性を表現する特徵量を導出する.

提案手法の全体像を図 1 に示す。提案手法ではまず，自然言語の英文のペア $A, B$ を入力と して, CCG パーザによる統語解析によって, $A, B$ を CCG の導出木に変換する. 次に, ラムダ 計算に基づく意味合成によって, CCGの導出木から高階述語論理式 $A^{\prime}, B^{\prime}$ に変換する。次に, 定理証明器を用いて，2つの論理式 $A^{\prime}, B^{\prime}$ の双方向の含意関係について，自然演繹による証明 を試みる。文から論理式への変換と文間の含意関係の証明には, ccg2lambda (Martínez-Gómez, Mineshima, Miyao, and Bekki 2016) を用いる. ccg2lambdaは, CCGに基づく統語解析の結果 を用いて文の意味を高階述語論理式で表現し，文間の含意関係について自動推論を行う統合的 システムである。 各入力文に対して, CCG の導出木と意味表示を出力し, また, 文ぺアに対し ては含意関係の判定結果を出力する。本研究では文間の含意関係の証明の実行過程を取得でき るように ccg2lambda を改良した ${ }^{1}$ 。この ccg2lambda が導出した文間の含意関係の証明の実行 過程と判定結果を用いて，文間の関連性に関する特徴量を設計する。最後に，ランダムフォレ ストを用いて, 文間類似度学習では回帰分析, 含意関係認識では含意・矛盾・不明の 3 值分類 を行う。次節以降で, 各手順の詳細を述べる。

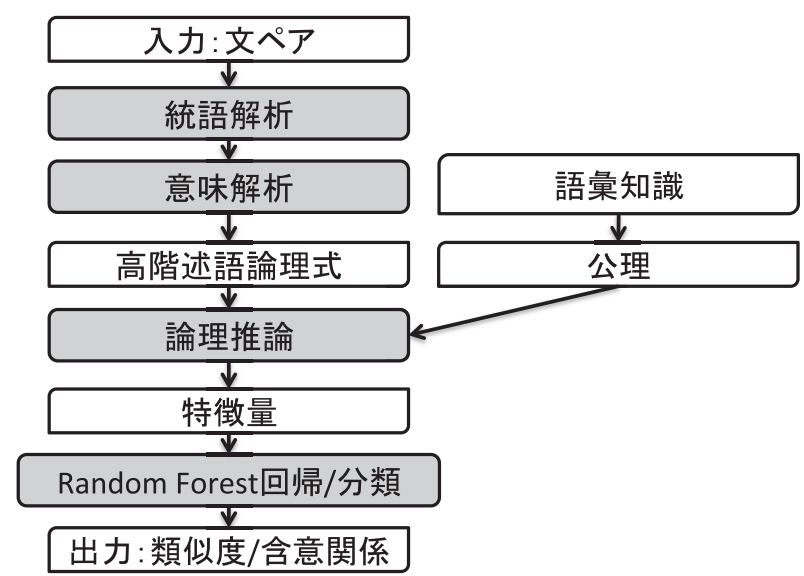

図 1 提案手法の全体像

\footnotetext{
1 改良したシステムは https://github.com/mynlp/ccg2lambda にて公開している.
} 


\subsection{CCG に基づく意味表現}

まず, CCGパーザによる統語解析によって, 英語の自然言語文を CCG の導出木に変換する. CCG は語彙化文法の一つであり, 統語構造から合成的に意味表示を導出することに適した文法 体系である，CCGでは，基本的な統語範疇として，N (普通名詞)，NP(名詞句），S(文) 等の 基底範疇が定義されている。また，複合範疇は基本範疇と二項演算子 $/, \backslash$ の組み合わせによっ て定義される。CCGは語の統語範疇と意味表示を記述する辞書と，語から句や文を構成する際 の統語構造と意味合成の計算方法を指定する少数の組合せ規則から成り立つ.

図 2 に提案手法に用いる CCG の代表的な組合せ規則を示す。たとえば，関数適用規則 $(>)$ を適用することによって,$X / Y$ という形の統語範疇および意味 $f$ をつ語は, その右側にある $Y$ という形の統語範疇および意味 $a$ をもつ語と結びつき， $X$ という統語範疇および意味 $f a$ を もつ句が形成される。

CCG の導出木から文の意味表示である高階述語論理式への変換は，ラムダ計算に基づいて行 われる。語の意味はラムダ項によって表現され，組合せ規則によってラムダ項の意味合成を行 い，文の意味表示となる論理式を導出する．

提案手法では，Neo-Davidsonian Event Semantics (Parsons 1990)に基づく意味表示を採用す る。たとえば, 他動詞文 (1a), 量化文 (2a), 否定量化文 (3a) はそれぞれ次のように分析される.

(1) a. Bob surprised Susan.

b. $\exists e(\operatorname{surprise}(e) \wedge(\operatorname{subj}(e)=\mathbf{b o b}) \wedge(\operatorname{dobj}(e)=\operatorname{susan}))$

(2) a. Some women are singing loudly.

b. $\exists x(\operatorname{woman}(x) \wedge \exists e(\operatorname{sing}(e) \wedge(\operatorname{subj}(e)=x) \wedge \operatorname{loudly}(e)))$

(3) a. No women are singing loudly.

b. $\neg \exists x(\operatorname{woman}(x) \wedge \exists e(\operatorname{sing}(e) \wedge(\operatorname{subj}(e)=x) \wedge \operatorname{loudly}(e)))$

$$
\begin{array}{cl}
\frac{X / Y: f \quad Y: a}{X: f a}> & \frac{Y: a \quad X \backslash Y: f}{X: f a}< \\
\frac{f: X / Y \quad g: Y / Z}{\lambda x \cdot f(g x): X / Z}>\mathbf{B} & \frac{g: Y \backslash Z \quad f: X \backslash Y}{\lambda x \cdot f(g x): X \backslash Z}<\mathbf{B} \\
\frac{f: X / Y \quad g: Y \backslash Z}{\lambda x \cdot f(g x): X \backslash Z}>\mathbf{B}_{\times} & \frac{g: Y / Z \quad f: X \backslash Y}{\lambda x \cdot f(g x): X / Z}<\mathbf{B}_{\times}
\end{array}
$$

図 2 CCG の代表的な組合せ規則。関数適用規則 $(<,>)$, 関数合成規則 $(>\mathbf{B},<\mathbf{B})$, 交差関数合成規則 $\left(>\mathbf{B}_{\times},<\mathbf{B}_{\times}\right)$ 
Neo-Davidsonian Event Semantics では, 動詞をイベントを項に持つ 1 項述語として分析し, 副詞 や前置詞などの修飾表現をイベントを項に持つ述語として扱う。そのため, (2a)や (3a)の loudly のような修飾表現を含む文も統一的に記述できるという利点がある。また，ここで採用する方 法では， $x$ が表す項がイベント $e$ を表す動詞に対して主語の関係にあることを $\operatorname{subj}(e)=x, x$ が表す項がイベント $e$ を表す動詞に対して直接目的語の関係にあることを $\operatorname{dobj}(e)=x$ のうう に表すことで，動詞の必須格にイベントを項にとる関数を対応させる。このため，個々の動詞 の必須格と非必須格の境界を定める必要がないという点で, 従来の Davidsonian 形式 (Davidson 1967）よりも柔軟な意味表現となっている. さらに, 動詞をイベントに対する 1 項述語として 統一的に扱うことで，動詞に関する公理もまた統一的に記述することが可能となり，自然言語 の推論により適した表現形式となっている。なお，項とイベントとの関係（意味役割）につい ては様々な分類手法が提案されている (Peter and Wilkins 1984; Ray 1990) が，本稿では英語 CCGBank (Hockenmaier and Steedman 2007) に基づくCCG の解析結果から確認できる項とイ ベントの関係を意味表示に反映する ${ }^{2}$.

本論文では, $\operatorname{subj}(e)=x, \quad \operatorname{dobj}(e)=y$ のようなイベントに関する機能的な関係を表す論理 式を機能論理式と呼び, 内容語を担う情報を表す $\operatorname{sing}(e), \operatorname{loudly}(e)$ のような論理式を内容論 理式と呼ぶことで区別する.

辞書では，統語範疇単位で意味を指定する意味割り当てのテンプレートと，量化や否定表現 などの論理語・機能語に対して語単位で意味を指定する語彙項目の 2 種類を使用する。文の意 味表現を合成的に与えるにあたって，イベントの量化をどのようにして正しく扱うかという問 題がある，量化名詞句や否定を含む文では，一般的にイベントの存在量化よりも量化名詞句や 否定が広いスコープをとることが知られている。そこで本論文では，先行研究 (Champollion 2015; Mineshima et al. 2016) に従い, 動詞自体をイベントの量化を導入する表現として扱う. また, 副詞等の修飾表現は, 動詞によって導入された存在量化子のスコープ内に出現しなくて はならない，そこで，動詞の型を繰り上げ，動詞が修飾表現を項にとるように扱う.

以上の分析に従った CCG 導出木の具体例として, 文 $(3 a)$ の CCG 導出木を図 3 に示す。ここ で，丁はトートロジーに対応する命題定項であり，丁の挿入は意味合成の過程で必要となる操 作である (Mineshima et al. 2015). 最終的に導出された論理式は (3b) の論理式と同值である.

ccg2lambdaの先行研究 (Martínez-Gómez, Mineshima, Miyao, and Bekki 2017) では, 複数の $\mathrm{CCG}$ パーザを組み合わせて統語解析に用いることによって, 構文的曖昧性が解消され，含意関 係の推論精度が向上したことが報告されている。提案手法では C\&C (Clark and Curran 2007), EasyCCG (Lewis and Steedman 2014), depccg (Yoshikawa, Noji, and Matsumoto 2017) という

\footnotetext{
2一例として, A tree is cut by a man のような受動態を含む文の場合は, CCG の続語解析の結果から受動態であ ることを判別できるため, 意味解析の結果得られた主語, すなわち, a man は cut が表すイベントに対して主語の 関係をもつ項とみなされる。
} 


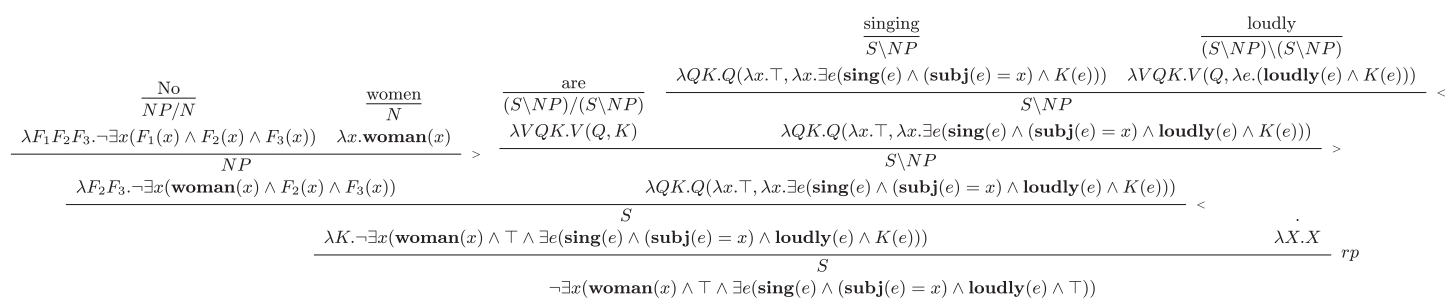

図 3 No women are singing loudly.の CCG 導出木と意味表示

3 種類の CCG パーザを用いて統語解析を行う。得られた 3 種類のパーズ結果を用いて意味合成 と推論を行い，適切なパーズ結果を選択する．含意関係の正解ラベルが付与されたデータセッ トによる評価においては，トレーニングデータから特徵量を抽出する際に，含意関係の正解ラ ベルと同じ結果を導出するパーズ結果を優先して採用する。正解ラベルと同じ結果を導出でき たパーズ結果が存在しなければ，統語解析に成功した結果を優先して採用する．含意関係の正 解ラベルが存在しないデータセットによる評価では, 統語解析に成功した結果を優先して採用 する。また，複数の CCG パーザの結果において，含意関係の判定結果（yes, no, unknownのい ずれか）が得られた場合は，より正確なパーズ結果を採用するため, パーザの精度が高い順に， depccg, EasyCCG， C\&Cの順に優先してパーズ結果を採用する.

\section{3 自然演繹による証明戦略の概要}

本節では，提案手法で用いる自然演繹による証明戦略の概要について述べる，文間の含意関 係とは一方の文の情報が他方の文の情報を含むという関係であり，方向性を持った関係である

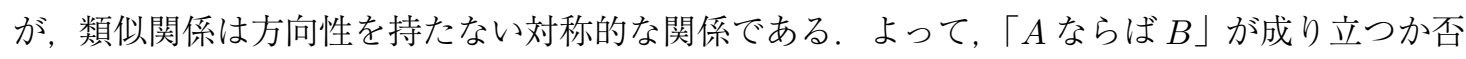
かという一方向の含意関係ではなく，「Aならば $B\rfloor 「 B$ ならば $A 」$ がそれぞれ成り立つか否かと いう双方向の含意関係の証明を試みることによって，文間の関連性に関してより多くの情報が 取得できると考えられる。そこで，本研究では文 $A, B$ 間の双方向の含意関係の証明を介して， 文 $A, B$ 間の関連性を表す特徵を獲得する.

文間の含意関係の証明には，高階論理・型理論に基づく定理証明器である Coq (Bertot and Castran 2010) を用いる. Coq は自然演繹に基づいて推論規則を適用し, 証明を行う。また, Ltac という記述言語を用いて証明探索の手続きを定義することによって, 証明の自動化が可能であ る. ccg2lambdaは Coqの一階述語論理の部分系に対する自動推論を含む自動証明機能と, 高階 の公理とを組み合わせることで, 自然言語の効率的な推論を可能にしている.

提案手法で用いる文間の含意関係の証明の全体的な流れは次の通りである。まず，文 $A, B$ を 論理式 $A^{\prime}, B^{\prime}$ に変換し, 一方の文を証明に用いる前提, 他方の文を証明対象である結論（ゴー ル）とみなして， $A^{\prime} \Rightarrow B^{\prime}, B^{\prime} \Rightarrow A^{\prime}$ の証明を行う。証明に失敗した場合は，結論を否定した 
$A^{\prime} \Rightarrow \neg B^{\prime}, B^{\prime} \Rightarrow \neg A^{\prime}$ の証明を行う。これは結論の否定が証明可能な場合は, 結論も結論の否定 も証明不可能な場合と比較して, 論理式が共通の部分を多く含み, 文間の関連度が高くなることを 考慮している。実際に, 評価に用いる文の意味的類似度データセットである SemEval2014 Task1 の Sentences Involving Compositional Knowledge (SICK) (Marelli, Menini, Baroni, Bentivogli, Bernardi, and Zamparelli 2014) では，含意関係の正解ラベルが「矛盾」である文ぺアの 7 割に おいて，正解の類似度スコアが高く設定されている。

結論の証明, 結論の否定の証明の両方に失敗した場合は, 前提のプールにある論理式からは導 くことができない論理式（サブゴール）が結論中に残っていることを意味する，そこで次に，前 提のプールにある論理式と証明できないと判定されたサブゴールとの述語間の意味的関係につい て, 語彙知識を用いてチェックし, 公理の生成を試みる。生成した公理を用いて再度 $A^{\prime} \Rightarrow B^{\prime}$, $B^{\prime} \Rightarrow A^{\prime}$ の証明を試みる。 $A^{\prime} \Rightarrow B^{\prime}, B^{\prime} \Rightarrow A^{\prime}$ の証明に失敗した場合は, 生成した公理を用いて 結論を否定した $A^{\prime} \Rightarrow \neg B^{\prime}, B^{\prime} \Rightarrow \neg A^{\prime}$ の証明を試みる.

公理を生成しても，結論と結論の否定の両方の証明に失敗した場合は, $A^{\prime} \Rightarrow B^{\prime}, B^{\prime} \Rightarrow A^{\prime}$ の 証明の途中で証明不可能と判定されたサブゴールをスキップして, 強制的に証明を終了させる. ここまでの推論における，生成した公理に関する情報や，強制的にスキップしたサブゴールの 情報といった推論の情報を Coq の出力結果から抽出し, 文間の関連性を表す特徵量として利用 する。

\section{4 含意関係の証明}

含意関係の証明の例として，以下の 2 つ文 $A, B$ 間の含意関係について，自然演繹による証 明を試みる。

A: $A$ man is singing in a bar.

$B$ : $A$ man is singing.

文 $A, B$ は統語解析, 意味解析を経て, 以下のような論理式 $A^{\prime}, B^{\prime}$ に変換できる.

$$
\begin{aligned}
& A^{\prime}: \exists e_{1} x_{1} x_{2}\left(\operatorname{man}\left(x_{1}\right) \wedge \operatorname{sing}\left(e_{1}\right) \wedge\left(\operatorname{subj}\left(e_{1}\right)=x_{1}\right) \wedge \operatorname{bar}\left(x_{2}\right) \wedge \operatorname{in}\left(e_{1}, x_{2}\right)\right) \\
& B^{\prime}: \exists e_{1} x_{1}\left(\operatorname{man}\left(x_{1}\right) \wedge \operatorname{sing}\left(e_{1}\right) \wedge\left(\operatorname{subj}\left(e_{1}\right)=x_{1}\right)\right)
\end{aligned}
$$

まず, $A^{\prime} \Rightarrow B^{\prime}$ について, 自然演繹による証明を試みる。ここで, 論理式 $A^{\prime}, B^{\prime}$ は推論規則を 適用することによって分解することができる。図 4 に本研究で用いる推論規則の例を示す。自 然演繹の推論規則には導入規則と除去規則の 2 つがある。導入規則は結論をどのように証明す るかを指定するための規則である。除去規則は前提をどのように証明に利用するかを指定する ための規則であるが，主に前提のプールにある論理式をより小さい論理式に分解するために用 いられる。

$A^{\prime} \Rightarrow B^{\prime}$ の証明プロセスを図 5 に示す。図 5 において, 論理式 $A^{\prime}$ は前提 $P_{0}$, 論理式 $B^{\prime}$ は結 


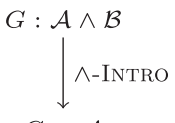

$G_{1}: \mathcal{A}$

$G_{2}: \mathcal{B}$

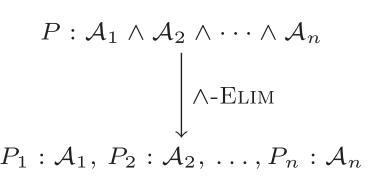

$P_{1}: \mathcal{A}_{1}, P_{2}: \mathcal{A}_{2}, \ldots, P_{n}: \mathcal{A}_{n}$

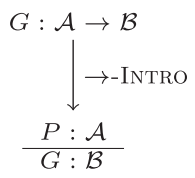

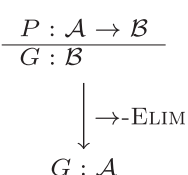

$G: \mathcal{A}$
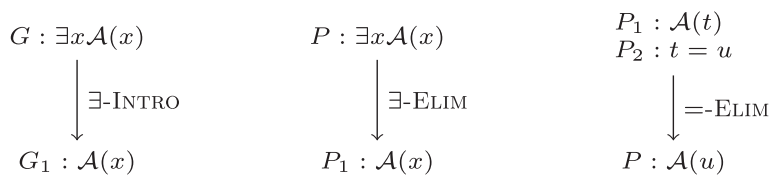

図 4 自然演繹の証明で用いる推論規則の例. $P, P_{1}, \ldots P_{n}$ は前提の論理式, $G, G_{1}, G_{2}$ は結論（ゴール） の論理式を表す。いずれの推論規則においても，規則適用前の論理式は矢印の上部に，規則適用後 の論理式は矢印の下部に示す.

$$
\begin{aligned}
& P_{0}: \exists e_{1} x_{1} x_{2}\left(\operatorname{man}\left(x_{1}\right) \wedge \operatorname{sing}\left(e_{1}\right) \wedge\left(\operatorname{subj}\left(e_{1}\right)=x_{1}\right) \wedge \operatorname{bar}\left(x_{2}\right) \wedge \operatorname{in}\left(e_{1}, x_{2}\right)\right) \\
& \hline G_{0}: \exists e_{1} x_{1}\left(\operatorname{man}\left(x_{1}\right) \wedge \operatorname{sing}\left(e_{1}\right) \wedge\left(\operatorname{subj}\left(e_{1}\right)=x_{1}\right)\right) \\
& \downarrow \text {-ELIM }\left(P_{0}\right), \exists \text {-INTRo }\left(G_{0}\right) \\
& \quad \downarrow \wedge \text {-ELIM }\left(P_{1}\right), \wedge \text {-INTRO }\left(G_{1}\right) \\
& \frac{P_{1}: \operatorname{man}\left(x_{1}\right) \wedge \operatorname{sing}\left(e_{1}\right) \wedge\left(\operatorname{subj}\left(e_{1}\right)=x_{1}\right) \wedge \operatorname{bar}\left(x_{2}\right) \wedge \operatorname{in}\left(e_{1}, x_{2}\right)}{G_{1}: \operatorname{man}\left(x_{1}\right) \wedge \operatorname{sing}\left(e_{1}\right) \wedge\left(\operatorname{subj}\left(e_{1}\right)=x_{1}\right)} \\
& P_{2}: \operatorname{man}\left(x_{1}\right), P_{3}: \operatorname{sing}\left(e_{1}\right), P_{4}: \operatorname{subj}\left(e_{1}\right)=x_{1}, P_{5}: \operatorname{bar}\left(x_{2}\right), P_{6}: \operatorname{in}\left(e_{1}, x_{2}\right) \\
& \hline G_{2}: \operatorname{man}\left(x_{1}\right), G_{3}: \operatorname{sing}\left(e_{1}\right), G_{4}: \operatorname{subj}\left(e_{1}\right)=x_{1}
\end{aligned}
$$

図 52 文間の含意関係の証明プロセスの例

論 $G_{0}$ に配置される. $P_{0}$ と $G_{0}$ は除去規則 $(\wedge$-ELIM, ヨ-ELIM) と導入規則 $(\wedge-$ Intro, $\exists-I N T R O)$ の適 用によって，前提の集合 $\mathcal{P}=\left\{P_{2}, P_{3}, P_{4}, P_{5}, P_{6}\right\}$ とサブゴールの集合 $\mathcal{G}=\left\{G_{2}, G_{3}, G_{4}\right\}$ に分解 される．証明はサブゴール $G_{j}$ と述語と項が一致する前提 $P_{i}$ を探索する形で進められ, マッチす る前提が見つかればそのサブゴールを解決できる。全てのサブゴールが解決できれば $A^{\prime} \Rightarrow B^{\prime}$ の証明が示せたことになる。この例では，サブゴール $G_{2}, G_{3}, G_{4}$ と前提 $P_{2}, P_{3}, P_{4}$ の述語と項 がそれぞれマッチし，全てのサブゴールが解決できるため，公理を生成せずに $A^{\prime} \Rightarrow B^{\prime}$ を示す ことができる。

次に，図 5 の前提 $P_{0}$ と結論 $G_{0}$ を逆転させて, $B^{\prime}$ を証明の前提， $A^{\prime}$ を証明の結論とみな

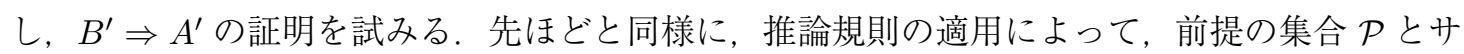


ブゴール $\mathcal{G}$ の集合を得ることができる.

$$
\begin{aligned}
& \mathcal{P}=\left\{P_{2}: \operatorname{man}\left(x_{1}\right), P_{3}: \operatorname{sing}\left(e_{1}\right), P_{4}: \operatorname{subj}\left(e_{1}\right)=x_{1}\right\} \\
& \left.\mathcal{G}=\left\{G_{2}: \operatorname{man}\left(x_{1}\right), G_{3}: \operatorname{sing}\left(e_{1}\right), G_{4}: \operatorname{subj}\left(e_{1}\right)=x_{1}, G_{5}: \operatorname{bar}\left(x_{2}\right), G_{6}: \operatorname{in}\left(e_{1}, x_{2}\right)\right)\right\}
\end{aligned}
$$

この場合, 2 つのサブゴール $G_{5}, G_{6}$ は前提のプールにあるどの論理式ともマッチしないため, 解決できずに残り， $B^{\prime} \Rightarrow A^{\prime}$ の証明に失敗する。そこで次に，語彙知識からの公理生成を試み る。しかし, この場合は残っているサブゴールの述語 $\operatorname{bar}\left(x_{2}\right)$ の項 $x_{2}$ をシェアする述語が前 提 $\mathcal{P}$ 中に存在しないため, 公理を生成することができない. そのため, このような例からも部 分的な証明プロセスの情報を Coq から取得するため, 本研究では解決できなかったサブゴール $\operatorname{bar}\left(x_{2}\right), \operatorname{in}\left(e_{1}, x_{2}\right)$ をスキップして, 強制的に $B^{\prime} \Rightarrow A^{\prime}$ の証明を終了させる.

\section{5 矛盾関係の証明}

矛盾関係の証明について述べる上で，まず否定の推論規則について説明する，否定の基本的

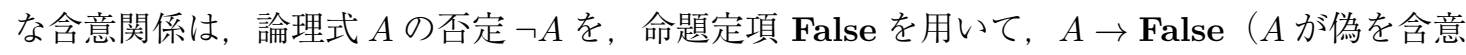
する）と定義することで捉えることができる。この定義に従って，否定の推論規則は図 6 に示 す規則を用いる. 否定の導入規則 (ᄀ-INTRO) は, もしゴールの論理式が $\mathcal{A}$ という形であれば, $\mathcal{A}$ を新たに前提に加えて，矛盾 (False) の証明を試みるという形をとる。一方，否定の除去規

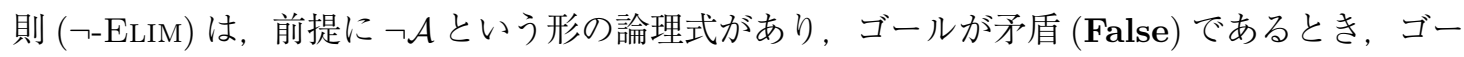
ルを $\mathcal{A}$ に更新しこの新たなゴールの証明を試みる, というものである.

矛盾関係の証明の例として，以下の 2 つ文 $A, B$ 間の矛盾関係について，自然演繹による証 明を試みる。

A: No man is singing.

$B$ : There is a man singing loudly.

図 7 に矛盾関係の証明プロセスを示す。文 $A, B$ は論理式 $A^{\prime}, B^{\prime}$ に変換後, 前提 $P_{0}, P_{1}$ にそれ ぞれ配置され, 結論 $G_{0}$ には False が配置される. 否定の除去規則 -ELIM を $P_{0}$ に適用するこ とによって，ゴールは $G_{1}$ に更新される。ここで，除去規則を適用することによって，前提 $P_{1}$ は前提の集合 $P_{2}, P_{3}, P_{4}, P_{5}$ に分解される. 同様に, 導入規則を適用することで, ゴール $G_{1}$ はサ

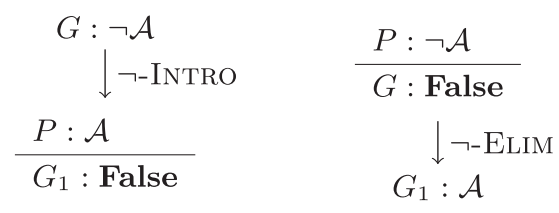

図 6 否定の推論規則 


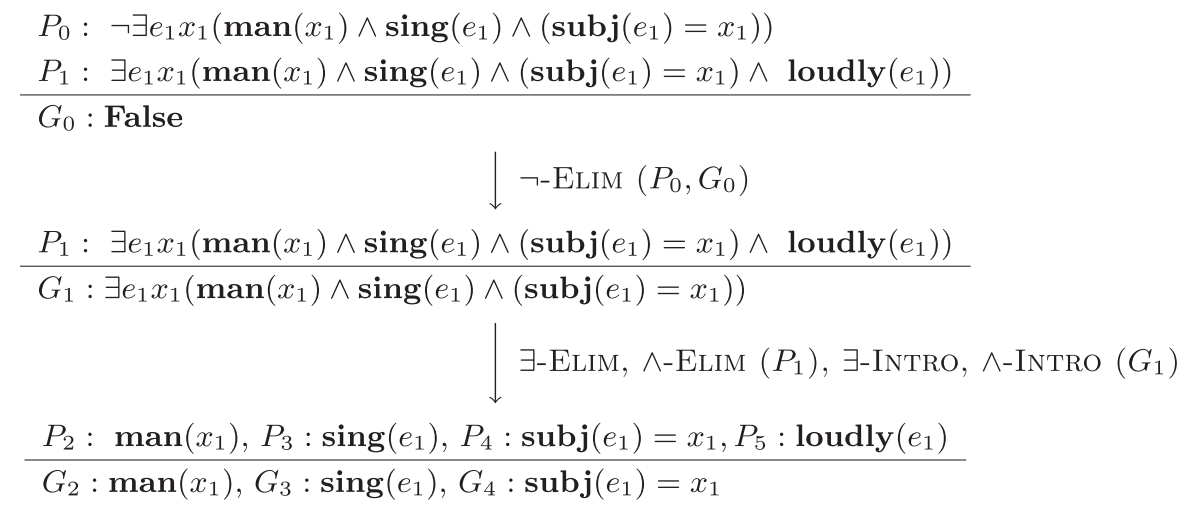

図 72 文間の矛盾関係の証明プロセスの例

ブゴールの集合 $G_{2}, G_{3}, G_{4}$ に分解される．全てのサブゴールが前提とマッチするため，文 $A, B$ の矛盾関係，すなわち， $A^{\prime} \Rightarrow \neg B^{\prime}$ を示すことができる.

\section{6 語彙知識を用いた公理の生成}

本節では，自然演繹の推論に用いる公理の具体的な生成手順について述べる。まず，証明の 途中で証明不可能と判定されたサブゴールに関して, 前提と結論で同じ項をシェアしている述 語を生成する公理の候補として絞り込む。ささらに，同じ項をシェアしている述語の中でも，項 の格が同じである述語について優先して公理を生成する.

公理生成を導入した証明の例として，以下の 2 つの文 $A, B$ 間の含意関係の証明を考える.

A: A kitten plays in a house colored in green.

$B$ : A young cat plays in a green house.

文 $A, B$ は統語解析，意味解析を経て，以下のような論理式 $A^{\prime}, B^{\prime}$ に変換できる.

$$
\begin{aligned}
A^{\prime}: & \exists e_{1} e_{2} x_{1} x_{2} x_{3}\left(\operatorname{kitten}\left(x_{1}\right) \wedge \operatorname{play}\left(e_{1}\right) \wedge\left(\operatorname{subj}\left(e_{1}\right)=x_{1}\right)\right. \\
& \left.\wedge \operatorname{house}\left(x_{2}\right) \wedge \operatorname{color}\left(e_{2}\right) \wedge\left(\operatorname{dobj}\left(e_{2}\right)=x_{2}\right) \wedge \operatorname{in}\left(e_{1}, x_{2}\right) \wedge \operatorname{green}\left(x_{3}\right) \wedge \operatorname{in}\left(e_{2}, x_{3}\right)\right) \\
B^{\prime}: & \exists e_{1} x_{1} x_{2}\left(\operatorname{young}\left(x_{1}\right) \wedge \operatorname{cat}\left(x_{1}\right) \wedge \operatorname{play}\left(e_{1}\right) \wedge\left(\operatorname{subj}\left(e_{1}\right)=x_{1}\right)\right. \\
& \left.\wedge \operatorname{green}\left(x_{2}\right) \wedge \operatorname{house}\left(x_{2}\right) \wedge \operatorname{in}\left(e_{1}, x_{2}\right)\right)
\end{aligned}
$$

これら 2 つ論理式 $A^{\prime}, B^{\prime}$ について， $A^{\prime}$ を証明の前提， $B^{\prime}$ を証明の結論（ゴール）とみな し，公理生成を行わずに $A^{\prime} \Rightarrow B^{\prime}$ の証明を試みる。図 5 と同様に $A^{\prime} \Rightarrow B^{\prime}$ の含意関係の証明を 進めると，下記のような前提の集合 $\mathcal{P}$ とサブゴール $\mathcal{G}$ の集合が得られる。 このステップでは, 存在量化子が除去され, $A^{\prime}, B^{\prime}$ に共通する述語については, 変数の単一化が起こっている. 


$$
\begin{aligned}
\mathcal{P}=\{ & P_{1}: \operatorname{kitten}\left(x_{1}\right), P_{2}: \operatorname{play}\left(e_{1}\right), P_{3}: \operatorname{subj}\left(e_{1}\right)=x_{1}, P_{4}: \operatorname{house}\left(x_{1}\right), \\
& \left.P_{5}: \operatorname{color}\left(e_{2}\right), P_{6}: \operatorname{dobj}\left(e_{2}\right)=x_{2}, P_{7}: \operatorname{in}\left(e_{1}, x_{2}\right), P_{8}: \operatorname{green}\left(x_{3}\right), P_{9}: \operatorname{in}\left(e_{2}, x_{3}\right)\right\} \\
\mathcal{G}=\{ & \left\{G_{1}: \operatorname{young}\left(x_{1}\right), G_{2}: \operatorname{cat}\left(x_{1}\right), G_{3}: \operatorname{green}\left(x_{2}\right)\right\}
\end{aligned}
$$

この例では, young $\left(x_{1}\right), \operatorname{cat}\left(x_{1}\right), \operatorname{green}\left(x_{2}\right)$ という 3 つのサブゴールが残り, 証明に失敗する. ここで, 前提中の論理式 $\operatorname{kitten}\left(x_{1}\right)$ と共通の項 $x_{1}$ をシェアしているサブゴール $\operatorname{young}\left(x_{1}\right), \operatorname{cat}\left(x_{1}\right)$ が生成する公理の候補となる。語彙知識から young cat と kitten 間の意味的関係が確認できれ ば, young cat と kitten 間に関する公理を生成でき，生成した公理を利用することで，これら 2 つのサブゴールを解決できる。なお，証明に用いた公理の数や確信度はのちに文間の関連性を 学習するための特徵量として使用するが, $\forall x \cdot \operatorname{kitten}(x) \Rightarrow \operatorname{young}(x), \forall x \cdot \operatorname{kitten}(x) \Rightarrow \operatorname{cat}(x)$ のように, 複数のサブゴールに関して同じ前提から導出した公理については, まとめて 1 つのフ

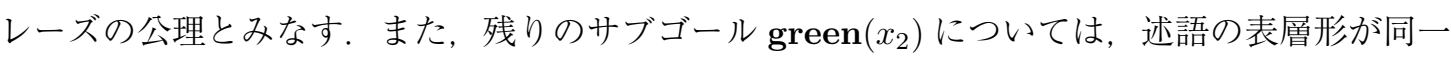
である論理式 $\operatorname{green}\left(x_{3}\right)$ が前提中に存在するが, 項は一致していない. このように，サブゴー ルに残っている述語と表層形が完全に一致する述語が前提中に含まれる場合に限り, 例外的に, 述語の型や項が異なっていても公理を生成して証明に用いる.

本研究では公理生成に用いる語彙知識として, WordNet (Miller 1995) と, Word2Vec (Mikolov, Sutskever, Chen, Corrado, and Dean 2013) で学習した単語べクトルを用いる. まず, WordNet を用いて形態変化, 派生形, 同義語, 反意語, 上位語, 類似性, 下位語の順に, 前提と結論中 の述語間の意味的関係をチェックし，いずれかの関係にマッチした場合は確信度つき公理を生 成する。 WordNetに述語間の関係が存在しない場合は, Word2Vecで学習した単語べクトルを 用いて前提と結論中の述語間の類似度を計算し, やはり確信度つきの公理を生成する。本研究 では, Google News Corpus（約 30 億語）で学習済みの 200 次元の単語ベクトルを語彙知識に用 いる。 ここで，公理の確信度には，述語間の類似度を採用し，生成された公理の中で確信度が 最も高い公理を証明に採用する。また, 確信度が䦨值よりも低い公理は意味的関係が低い公理 であるとみなして採用しない. 公理の確信度はいずれも 0.0 から 1.0 の範囲の值をとり, 本研究 では公理の確信度の閾值を 0.25 とする. WordNetを用いて公理を生成した場合は, 述語間に共 通する上位概念への最短経路の長さを公理の確信度とし, Word2Vec を用いて公理を生成した 場合は, Word2Vecのコサイン類似度を公理の確信度とする。

\section{7 証明に基づく特徵量の導出}

ここまでの自然演繹の証明の実行過程と結果に関する情報から, 計 9 種類の特徴量を導出す る.いずれも 0.0 から 1.0 の範囲の值に正規化する。

- 公理の数と公理の確信度

証明に利用した公理の数と確信度をそれぞれ特徵量に用いる。複数の公理を生成した場 
合は, 導入した各公理の確信度の平均を公理の確信度の特徴量として採用する。また，公 理を 1 つも利用しなかった場合は，公理の確信度の特徵量を 1.0 とする.

・証明可能なサブゴールの数の割合

証明可能なサブゴールの数の割合が高いほど文間の関連度が高くなると仮定して $n / m$ $(m$ : 前提のプールに現れる論理式の数, $n$ : 証明でスキップしなかったサブゴールの数 $)$ を特徵量として導出する。ここで，サブゴールとして残る論理式には $\operatorname{bar}\left(x_{2}\right)$ のような 内容論理式と, $\operatorname{subj}\left(e_{1}\right)=x_{1}$ のような機能論理式の 2 種類がある。 そこで, 内容論理 式と機能論理式のそれぞれについてサブゴールの数の割合を計算し，それぞれ別の特徴 量とした。また，公理生成による証明を試みた場合は，証明可能なサブゴールの割合は 公理生成の前後によって変わるため, 公理生成前と公理生成後のそれぞれについてサブ ゴールの数の割合を計算し，それぞれ別の特徴量とした。

・証明不可能なサブゴールの項の関係

文の主語や目的語が異なると，修飾語が異なる場合よりも文間の関連度が低くなると仮 定して，証明不可能と判定されたサブゴールの項とイベントの関係をチェックする．本 研究では, 内容論理式中の主語 (subj), 直接目的語 ( dobj), 間接目的語 (iobj)をチェッ ク対象とする。証明不可能と判定された全てのサブゴールにおける当該サブゴールの割 合を特徵量として導出する.

・証明のステップ数

証明が簡潔であるほど文間の関連度が高くなると仮定して，自然演繹の証明図の推論ス テップ数を特徵量に用いる.

- 推論規則の適用回数

証明において推論規則の適用回数が多いほど証明が複雑になり，文間の関連度が低くな ると仮定して，全推論規則の適用回数における各推論規則の適用回数の割合を特徴量に 用いる。提案手法では図 4 に示した連言の除去規則と導入規則 $(\wedge-E L I M, \wedge-I N T R O)$, 含 意の除去規則と導入規則 $(\rightarrow$-ELIM, $\rightarrow-$ INTRO) , 存在量化の除去規則と導入規則 $(\exists$-ELIM, $\exists$-INTRO), 等号の除去規則 (=-ELIM) という計 7 種類の推論規則を対象とする.

- 証明の結果

結論が証明可能か, 結論の否定が証明可能か, 結論も結論の否定も証明不可能かチェッ クし，それぞれ該当する場合は 1.0 , 該当しない場合は 0.0 を特徵量とする.

- 前提と結論における述語の一致率

前提と結論との間で述語が一致しているほど，文間の意味的関係を証明できる可能性が 高いことを考慮して，前提と結論で述語が一致している割合を特徵量に用いる.

- 前提と結論における型の一致率

前提と結論との間で論理式の型が一致しているほど，文間の意味的関係を証明できる可 
能性が高いことを考慮して，前提と結論で型が一致している割合を特徵量に用いる.

- 否定演算子の有無

前提と結論のどちらか一方だけに否定演算子 (ᄀ) が含まれる場合と, 両方に含まれる, または，どちらにも含まれない場合とでは，前者の方が文間の関連度が低くなると仮定 して, 前者の場合は 0.0 , 後者の場合は 1.0 として特徵量に用いる.

\section{8 表層情報と外部知識から導出した特徵量の設計}

提案手法では学習精度を向上させるため, 表層情報と外部知識から導出した特徵量を自然演 繹の証明に基づく特徵量と組み合わせて用いる，表層情報と外部知識から導出した特徵量は 10 種類の特徵量を用いる。特徴量はいずれも 0.0 から 1.0 の範囲の值に正規化する.

- 品詞の一致率

文中の各単語の品詞 (本研究で使用する品詞は Penn Treebank 品詞体系に準ずる) を C\&C POS tagger (Curran and Clark 2003) を用いてチェックし，2 文間において単語の品詞が 一致する割合を特徴量に用いる。

- 名詞の一致率 文中の名詞をレンマ化し，2 文間の名詞が一致する割合を特徵量に用いる.

- 動詞の一致率 文中の動詞をレンマ化し，2文間の動詞が一致する割合を特徵量に用いる.

- 文字列の類似度 $D i f f l i b^{3}$ を用いて文字列の類似度を計算し，計算結果を特徴量に用いる.

- 同義語集合の一致率

2 文中の全ての単語について，同義語集合をWordNet を用いてチェックし， 2 文間の同 義語集合の一致率を特徵量に用いる.

- 概念間の距離

一方の文と他方の文の全ての単語間について, 単語間類似度をWordNet の概念間の距離 を用いて導出し, 概念間の距離の平均を特徵量に用いる.

- 文の長さ

2 文間の文字数の差と, 2 文間の文字数の平均を特徵量に用いる.

・ ベクトル空間モデルにおけるコサイン類似度

$\mathrm{TF} / \mathrm{IDF}$ ベクトル間のコサイン類似度, latent semantic analysis (LSA) (Deerwester, Dumais, Landauer, and Harshman 1990) ベクトル間のコサイン類似度, latent Dirichlet allocation (LDA) (Blei, Ng, and Jordan 2003) ベクトル間のコサイン類似度をそれぞれ特

\footnotetext{
${ }^{3}$ https://docs.python.org/3.5/library/difflib.html
} 
徵量に用いる. 各ベクトルの次元は 200 次元とする.

・ CCG 導出木のマッピングコスト

文ぺアの導出木の形が似ていないほど，一般的には文間の関連度が低くなることが見达 まれる。そこで，文ぺアの CCG 導出木の各ノード間の対応度合い（CCG 導出木のマッ ピングコスト) を計算する手法 (Martínez-Gómez and Miyao 2016) を用いて, マッピン グコストを計算する。このマッピングコストを文ペアの導出木のノード数合計で除算し た值を特徵量に用いる.

- 受動態表現の有無

前提と結論のどちらか一方だけに受動態表現が含まれる場合と，両方に含まれる，また は，どちらにも含まれない場合とでは，前者の方が類似度が低くなると仮定して，一方 の文と他方の文の受動態表現の有無をチェックし, 前者の場合は 0.0 , 後者の場合は 1.0 として特徴量に用いる.

\section{9 文の関連度学習}

導出した特徵量を用いて, 文の意味類似度と含意関係を予測する。本研究では, ロジスティッ ク，SVM，ランダムフォレストという 3 種類の学習モデルで事前学習を行った結果，文の意味 類似度学習はランダムフォレスト回帰, 含意関係認識ではランダムフォレスト分類を学習モデ ルとして採用する。ハイパーパラメータはグリッドサーチを用いて最適化する.

\section{4 実験}

\section{1 データセット}

文の意味的類似度と含意関係認識の評価用データセットである SemEval2014 Task1 SICK デー タセット (Marelli et al. 2014) と，文の意味的類似度の評価用データセットである SemEval2012 MSR-video データセット (Agirre, Cer, Diab, and Gonzalez-Agirre 2012)の 2 種類のデータセッ トを用いて，提案手法の評価を行った。

SICK は，2つの文の意味的類似度と含意関係を予測する夕スクであり，表 1 に示すように， 類似度と含意関係 (yes, no, unknown) が人手によって付与されている. 類似度は 1.0 から 5.0 の 範囲の值で付与されている。このデータセットには計 9,927 件の文ペアが含まれており，その うち訓練データ, 開発データ, テストデータはそれぞれ 4,500 件, 500 件, 4,927 件含まれてい る. MSR-video は表 2 に示すように，含意関係のラベルは付与されておらず，類似度の正解ス コアのみが 0.0 から 5.0 の範囲の值で付与されており, 開発データ，テストデータが 750 件ずつ 含まれている.SICK データセットに含まれる文ぺアの方がMSR-video データセットに含まれ る文よりも単語数が多くなっており，それぞれのデータセットにおける一文あたりの平均単語 
表 1 SICK データセットに含まれる文ぺアの例

\begin{tabular}{l|c|c}
\hline \multicolumn{1}{c|}{ 文ペア } & 含意関係 & 類似度 \\
\hline $\begin{array}{l}\text { A dog is chasing another and is holding a stick in its mouth } \\
\text { A dog is chasing another and is holding a piece of wood in its mouth }\end{array}$ & Yes & 4.6 \\
\hline $\begin{array}{l}\text { There is no dog running and carrying an object in its mouth } \\
\text { Two dogs are running and carrying an object in their mouths }\end{array}$ & No & 3.5 \\
\hline $\begin{array}{l}\text { The girl, who is little, is combing her hair into a pony tail } \\
\text { A man in a red shirt is doing a trick with the rollerblades }\end{array}$ & Unknown & 1.2 \\
\hline $\begin{array}{l}\text { Two men are taking a break from a trip on a snowy road } \\
\text { Two men are holding bikes and standing on the side of a road covered of snow }\end{array}$ & Unknown & 3.8 \\
\hline
\end{tabular}

表 2 MSR-video データセットに含まれる文ぺアの例

\begin{tabular}{l|c}
\hline \multicolumn{1}{c|}{ 文ペア } & 類似度 \\
\hline $\begin{array}{l}\text { The man hit the other man with a stick } \\
\text { The man spanked the other man with a stick }\end{array}$ & 4.2 \\
\hline $\begin{array}{l}\text { There is no man eating some food } \\
\text { A man is playing a flute }\end{array}$ & 2.7 \\
\hline $\begin{array}{l}\text { A woman is slicing big pepper } \\
\text { A dog is moving its mouth }\end{array}$ & 0.0 \\
\hline
\end{tabular}

数は, SICK データセットは 10 単語, MSR-video データセットは 6 単語である.

\section{2 既存手法との比較評価の概観}

\subsection{1 文間類似度学習}

まず，文間類似度学習の評価を行った，なお，評価指標は，各夕スクで標準的に使用されてい る評価指標に基づいて, SICK データセットについては, 提案手法によって計算された類似度ス コアと, データセットに付与された正解スコアとの Pearson 相関係数 $\gamma$, Spearman 相関係数 $\rho$, 平均二乗誤差 (MSE) という 3 種類の指標を, MSR-video データセットについては Pearson 相関 係数 $\gamma$ のを用いる。比較対象は, SICK データセット, MSR-video データセットにおける最 高精度のモデル (Mueller and Thyagarajan 2016; Bär, Biemann, Gurevych, and Zesch 2012) と, 推論を用いた既存手法として，先行研究で紹介したThe Meaning Factory (Bjerva et al. 2014), UTexas (Beltagy et al. 2014) とする.

表 3 にSICK データセットにおける提案手法と既存手法との類似度学習の評価結果を示す. 提案手法の結果と推論を用いた既存手法の結果とを比較すると, Pearson 相関係数と Spearman 相関係数に関しては, 提案手法は推論を用いた既存手法よりも高精度を達成した。一方で, MSE に関しては，既存手法よりも精度が低かった。この原因としては複数の要因が挙げられるが, 大きく分けて統語解析によるエラー，意味表示の誤りによるエラー，語彙知識の不足などに起 
表 3 提案手法と既存手法との類似度学習の評価結果 (SICK)

\begin{tabular}{l|c|c|c}
\hline & $\gamma$ & $\rho$ & MSE \\
\hline Mueller et al. (2016) LSTM & 0.882 & 0.835 & 0.229 \\
提案法 (WordNet) & $\mathbf{0 . 8 4 2}$ & $\mathbf{0 . 7 9 9}$ & $\mathbf{0 . 2 9 9}$ \\
提案法 (WordNet+Word2Vec) & 0.841 & 0.798 & 0.300 \\
提案法 (Word2Vec) & 0.822 & 0.768 & 0.329 \\
The Meaning Factory & 0.827 & 0.772 & 0.322 \\
UTexas & 0.714 & 0.674 & 0.499 \\
\hline
\end{tabular}

表 4 提案手法と既存手法との類似度学習の評価結果 (MSR-video)

\begin{tabular}{l|c}
\hline & $\gamma$ \\
\hline SemEval2012 Best Score & 0.873 \\
提案法 (WordNet+Word2Vec) & 0.853 \\
提案法 (WordNet) & 0.848 \\
提案法 (Word2Vec) & 0.835 \\
UTexas & 0.830 \\
\hline
\end{tabular}

因する誤った推論によるエラーに分けられる。これらのエラーの詳細は 4.6 節で述べる。また, 文間類似度学習においては，提案手法は深層学習を用いたモデルによる最高精度に達しなかっ た.この原因を分析するため, テストデータ 4,927 件の文例に対して，提案手法と最高精度の モデルが予測した類似度スコアの比較を 4.5 節で行った.

表 4 に MSR-video データセットにおける提案手法と既存手法との類似度学習の評価結果を 示す. MSR-video データセットにおいても, 提案手法は推論を用いた既存手法よりも高精度を 達成した。また，公理生成に使用する語彙知識については，SICK では WordNetのみを語彙知 識に使用した場合, MSR-video ではWordNetとWord2Vec の両方を語彙知識に使用した場合 において最も精度が高かった。この原因はSICK と MSR-videoのデータセットの違いによる ものであると考えられる，4.1節で述べたように，SICK データセットに含まれる文ぺアの方が MSR-video データセットに含まれる文よりも単語数が多く, burrow a hole と dig the earthの言 い換えといったフレーズレベルの言い換えが多く含まれていた，そのため，MSR-videoデータ セットにおける評価では Word2Vec を用いて単語間の語彙知識を拡充することによって精度が 向上したが，SICK データセットにおいてはフレーズ間の公理を生成できず，Word2Vec の利用 によって誤った公理の過剩生成が起こり，精度が低下したと考えられる。公理の過剩生成に関 する具体例については 4.6 節で紹介する。 今後, フレーズレベルの語彙知識の拡充や公理生成 の改善を行うことで, 更なる精度向上が見込まれる. 


\subsection{2 含意関係認識}

次に, SICK データセットを用いて含意関係認識の評価を行った．評価指標は，適合率（yes， no と予測した文ペアに対して，正解ラベルと同じ結果だったケースの割合），再現率（正解ラ ベルがyes, no である文ペアに対して, 正解ラベルと予測ラベルが同じ結果だったケースの割 合), 正答率（yes, no, unknownのすべての文ペアに対して正解ラベルと予測ラベルが同じ結 果だったケースの割合）の 3 種類の指標を用いた。比較対象は，SICKデータセットにおける 最高精度のモデル (Yin and Schütze 2017) と, 推論を用いた既存手法として, 先行研究で紹介 した The Meaning Factory (Bjerva et al. 2014), UTexas (Beltagy et al. 2014)，また，改良前の ccg2lambda (Martínez-Gómez et al. 2017) の結果とする.

表 5 に提案手法と既存手法との含意関係認識の評価結果を示す。語彙知識に WordNetのみ, WordNet と Word2Vecの両方を使用した場合において，提案手法は最高精度を達成した。

公理生成に使用する語彙知識については, 含意関係認識のタスクにおいても WordNetのみを 語彙知識に使用した場合が最も精度が高かった。この原因について，4.2.1節で挙げた問題に加え て, Word2Vec を用いた場合は season（味付けする）と pour（注ぐ）間の意味的関係（Word2Vec における単語間類似度は 0.07 ), draw と paint 間の意味的関係（どちらも描くという意味である が, Word2Vecにおける単語間類似度は 0.155) といった, 多義語を含む単語間の意味的関係の チェックに失敗し, 公理が生成されない傾向が見られた。この結果から, 語義曖昧性を考慮し て単語間の意味的関係をチェックすることで，公理生成の改善が見込まれることが示唆された が,これは今後の課題とする.

\section{3 特徵量別の評価}

\subsection{1 文間類似度学習}

SICK データセットにおける, 各特徵量単独で文間類似度を学習した場合のモデルの評価結 果を表 6 に示す。この表が示すように，述語の一致率のみを特徴量に用いた場合が最も精度が 高かった。この結果は, 動詞・名詞の一致率と比較して, 論理式による意味表現が文の言語的

表 5 提案手法と既存手法との含意関係認識の評価結果 (SICK)

\begin{tabular}{l|c|c|c}
\hline & 適合率 & 再現率 & 正答率 \\
\hline 提案法 (WordNet) & $\mathbf{0 . 9 0 6}$ & $\mathbf{0 . 7 9 7}$ & $\mathbf{0 . 8 7 7}$ \\
提案法 (WordNet+Word2Vec) & 0.919 & 0.775 & 0.874 \\
提案法 (Word2Vec) & 0.870 & 0.733 & 0.841 \\
Yin and Schütze GRU (2017) & - & - & 0.871 \\
ccg2lambda & 0.970 & 0.636 & 0.831 \\
The Meaning Factory & 0.936 & 0.606 & 0.816 \\
UTexas & - & - & 0.734 \\
\hline
\end{tabular}


な情報を良質な形式で表現しているという先行研究の知見と合致している，導出木のマッピン グコストのみを使用した場合と受動態の有無のみを使用した場合は, Pearson 相関係数がほぼ 0 の值をとり，ほほ全ての文ペアで 3.5 の類似度スコアを予測していた。この結果から，これら の特徵量は単独では予測性能はないと考えられる。しかし，SICK データセット中の $76 \%$ の文 ペアに 3 から 5 の範囲の正解スコアが付与されているという正解スコアの分布の偏りが原因で, 導出木のマッピングコストのみを使用した場合と受動態の有無のみを使用した場合は予測性能 がないのにも関わらず, MSEの值は 1 程度の結果となったと考えられる。

全特徵量から各特徵量を取り除いて学習させた場合のモデルの評価結果を表 7 に示す。各特 徵量を単独で取り除いた結果は精度にほとんど変化が見られなかったが, 推論由来の特徴量の 中では証明の結果を取り除いた場合において，最も性能が低下した。この結果は $3.3 て ゙$ 述べた ように, SICK データセットでは含意関係が yes またはnoの文例において高い文間類似度が付 与されているため, 含意関係の証明の結果が文間類似度の予測性能に寄与していると考えられ る。また, 表層由来の特徵量の中ではべクトル空間モデルを取り除いた場合が最も性能が低下 した。この結果は, 文間類似度の予測においては表層的な一致率の影響が大きいことを示唆し ている.

表 6 各特徵量単独で学習した場合の類似度学習の 評価結果

\begin{tabular}{l|c|c|c}
\hline & $\gamma$ & $\rho$ & $\mathrm{MSE}$ \\
\hline 述語の一致率 & 0.6818 & 0.6105 & 0.5454 \\
サブゴールの数 & 0.6302 & 0.6012 & 0.6144 \\
推論規則 & 0.5611 & 0.5360 & 0.6988 \\
証明の結果 & 0.5493 & 0.5425 & 0.7117 \\
サブゴールの項の関係 & 0.5233 & 0.4965 & 0.7402 \\
証明のステップ数 & 0.4381 & 0.4386 & 0.8296 \\
公理の確信度 & 0.3787 & 0.3621 & 0.8732 \\
型の一致率 & 0.2333 & 0.2137 & 0.9641 \\
否定表現の有無 & 0.1615 & 0.2061 & 0.9924 \\
\hline 動詞・名詞の一致率 & 0.6560 & 0.5598 & 0.5805 \\
ベクトル空間モデル & 0.6086 & 0.5260 & 0.6602 \\
文字列の類似度 & 0.4857 & 0.4786 & 0.7788 \\
概念間の距離 & 0.4331 & 0.3953 & 0.8279 \\
同義語の一致率 & 0.4191 & 0.3849 & 0.8422 \\
品詞タグの一致率 & 0.3504 & 0.3484 & 0.8940 \\
文の長さの一致率 & 0.2621 & 0.2685 & 0.9490 \\
導出木のマッピングコスト & 0.0347 & 0.0208 & 1.0179 \\
受動態の有無 & 0.0987 & 0.1087 & 1.0092 \\
\hline 推論由来の特徵量のみ & 0.8114 & 0.7820 & 0.3483 \\
それ以外の特徵量のみ & 0.7847 & 0.7237 & 0.3937 \\
\hline 全特徵量 & 0.8420 & 0.7988 & 0.2990 \\
\hline
\end{tabular}

表 7 類似度学習のアブレーションの評価結果

\begin{tabular}{l|c|c|c}
\hline & $\gamma$ & $\rho$ & $\mathrm{MSE}$ \\
\hline 証明の結果 & 0.8355 & 0.7900 & 0.3077 \\
述語の一致率 & 0.8376 & 0.7976 & 0.3072 \\
公理の確信度 & 0.8388 & 0.7963 & 0.3044 \\
サブゴールの数 & 0.8407 & 0.7946 & 0.3013 \\
証明のステップ数 & 0.8409 & 0.7982 & 0.3008 \\
型の一致率 & 0.8410 & 0.7982 & 0.3007 \\
サブゴールの項の関係 & 0.8414 & 0.7995 & 0.3000 \\
否定表現の有無 & 0.8420 & 0.7988 & 0.2990 \\
推論規則 & 0.8430 & 0.8005 & 0.2972 \\
\hline ベクトル空間モデル & 0.8288 & 0.7925 & 0.3208 \\
動詞・名詞の一致率 & 0.8373 & 0.7934 & 0.3048 \\
受動態の有無 & 0.8396 & 0.7959 & 0.3027 \\
文の長さの一致率 & 0.8397 & 0.7978 & 0.3026 \\
文字列の類似度 & 0.8403 & 0.7970 & 0.3018 \\
同義語の一致率 & 0.8405 & 0.7974 & 0.3012 \\
概念間の距離 & 0.8406 & 0.7982 & 0.3011 \\
導出木のマッピングコスト & 0.8406 & 0.7980 & 0.3013 \\
品詞タグの一致率 & 0.8412 & 0.7983 & 0.3003 \\
\hline 推論の過程由来の特徵量のみ & 0.8326 & 0.7900 & 0.3146 \\
論理式由来の特徵量のみ & 0.8375 & 0.7958 & 0.3073 \\
\hline 推論由来の特徵量のみ & 0.7847 & 0.7237 & 0.3937 \\
それ以外の特徵量のみ & 0.8114 & 0.7820 & 0.3483 \\
\hline 全特徵量 & 0.8420 & 0.7988 & 0.2990 \\
\hline
\end{tabular}


推論を用いた特徵量をまとめて取り除いた場合は，推論以外の特徴量をまとめて取り除いた 場合と比較して，大きな性能低下が見られた。このことから，推論を用いた特徵量は推論以外 の情報を用いた特徵量よりも精度への影響が大きいことが示唆された．また，推論由来の特徴 量の中でも, 論理式由来の特徴量（述語の一致率, 型の一致率, 否定表現の有無）をまとめて取 り除いた場合よりも，推論の過程由来の特徵量（サブゴール，サブゴールの項の関係，ステップ 数, 推論規則, 公理の確信度) をまとめて取り除いた場合の方が性能低下が見られた。この結 果は証明の実行過程が文間の関連性を表す特徴として性能に寄与していることを示唆している。

\subsection{2 含意関係認識}

SICK データセットにおける，各特徵量単独で学習した場合の含意関係認識モデルの評価結果 を表 8 に示す，含意関係認識においては，証明の結果のみを特徵量に用いた場合が最も精度が高 かった. 型の一致率, 受動態の有無, 品詞夕グの一致率, 文の長さの一致率, 導出木のマッピン グコストは再現率が 0.1 以下と著しく低かった。これらの特徴量はほぼすべての文例で unknown を予測（型の一致率はすべて unknown と予測）し，単独では含意関係の予測性能がないことを 示唆している.

表 8 各特徵量単独で学習した場合の含意関係認識 の評価結果

\begin{tabular}{l|c|c|c}
\hline & 適合率 & 再現率 & 正答率 \\
\hline 証明の結果 & 0.5628 & 0.5104 & 0.7002 \\
サブゴールの数 & 0.5995 & 0.5913 & 0.7219 \\
公理の確信度 & 0.7292 & 0.3512 & 0.7158 \\
推論規則 & 0.6371 & 0.6026 & 0.7123 \\
述語の一致率 & 0.5628 & 0.5104 & 0.7002 \\
証明のステップ数 & 0.6465 & 0.4529 & 0.6908 \\
サブゴールの項の関係 & 0.7242 & 0.1620 & 0.6177 \\
否定表現の有無 & 0.6036 & 0.2990 & 0.6110 \\
型の一致率 & NaN & 0.0000 & 0.5651 \\
\hline ベクトル空間モデル & 0.5439 & 0.5400 & 0.6839 \\
動詞・名詞の一致率 & 0.7399 & 0.6737 & 0.6544 \\
文字列の類似度 & 0.4897 & 0.3701 & 0.6413 \\
同義語の一致率 & 0.4557 & 0.2302 & 0.6075 \\
概念間の距離 & 0.4062 & 0.2081 & 0.5911 \\
受動態の有無 & 0.9211 & 0.0330 & 0.5790 \\
品詞タグの一致率 & 0.3269 & 0.0160 & 0.5661 \\
文の長さの一致率 & 0.4619 & 0.0513 & 0.5649 \\
導出木のマッピングコスト & 0.2222 & 0.0009 & 0.5645 \\
\hline 推論由来の特徴量のみ & 0.9255 & 0.7491 & 0.8659 \\
それ以外の特徴量のみ & 0.7618 & 0.6474 & 0.7869 \\
\hline 全特徵量 & 0.9058 & 0.7971 & 0.8774 \\
\hline
\end{tabular}

表 9 含意関係認識のアブレーションの評価結果

\begin{tabular}{l|c|c|c}
\hline & 適合率 & 再現率 & 正答率 \\
\hline 証明のステップ数 & 0.9176 & 0.7345 & 0.8569 \\
サブゴールの数 & 0.9123 & 0.7782 & 0.8729 \\
推論規則 & 0.9202 & 0.7768 & 0.8755 \\
サブゴールの項の関係 & 0.9120 & 0.7853 & 0.8755 \\
否定表現の有無 & 0.9155 & 0.7853 & 0.8765 \\
証明の結果 & 0.9122 & 0.7877 & 0.8767 \\
公理の確信度 & 0.9110 & 0.7905 & 0.8771 \\
型の一致率 & 0.9267 & 0.8027 & 0.8771 \\
述語の一致率 & 0.9138 & 0.7891 & 0.8778 \\
\hline 受動態の有無 & 0.9134 & 0.7745 & 0.8710 \\
ベクトル空間モデル & 0.9016 & 0.7848 & 0.8712 \\
文字列の類似度 & 0.9125 & 0.7853 & 0.8753 \\
動詞・名詞の一致率 & 0.9051 & 0.7947 & 0.8763 \\
品詞タグの一致率 & 0.9161 & 0.7863 & 0.8769 \\
導出木のマッピングコスト & 0.9073 & 0.7971 & 0.8780 \\
文の長さの一致率 & 0.9145 & 0.7095 & 0.8782 \\
概念間の距離 & 0.9079 & 0.7980 & 0.8784 \\
同義語の一致率 & 0.9069 & 0.7976 & 0.8786 \\
\hline 推論の過程由来の特徴量のみ & 0.9038 & 0.7247 & 0.8238 \\
論理式由来の特徵量のみ & 0.9125 & 0.7900 & 0.8771 \\
\hline 推論由来の特徵量のみ & 0.7618 & 0.6474 & 0.7869 \\
それ以外の特徵量のみ & 0.9255 & 0.7491 & 0.8659 \\
\hline 全特徵量 & 0.9058 & 0.7971 & 0.8774 \\
\hline
\end{tabular}


全特徵量から各特徵量を取り除いて学習させた場合の含意関係認識モデルの評価結果を表 9 に示す。含意関係認識においても，各特徵量を単独で取り除いた結果は精度に大きな变動が見 られなかったが, 推論由来の特徵量は推論以外の情報を用いた特徵量よりも精度への影響が大 きいこと，推論由来の特徴量の中でも，推論の過程由来の特徴量（サブゴール, サブゴールの 項の関係, ステップ数, 推論規則, 公理の確信度）の方が論理式由来の特徵量（述語の一致率, 型の一致率, 否定表現の有無）よりも精度への影響が大きいことが示唆された.

また，含意関係認識においては，推論由来の特徵量の中では，証明のステップ数が性能に最 も大きく寄与する特徵量であることが示唆された。この結果は, 文間類似度の予測では文間の 表層的な一致率の影響が大きいのに対して, 含意関係の予測では文間の意味的な一致率の影響 が大きいという，含意関係認識と文間類似度学習の夕スク内容の違いを表していると考えられ る。さらに，公理の確信度の特徵量を取り除いた場合は性能が低下するのに対して，概念間の 距離や同義語の一致率の特徵量を取り除いた場合, 性能が向上した. 公理の確信度と概念間の 距離・同義語の一致率の特徵量の導出方法の比較からこの結果を考察すると, 概念間の距離と 同義語の一致率では 2 文中の全ての単語間について概念間の距離や同義語集合を計算し，その 平均を特徴量としているのに対して, 公理の確信度では 2 文間の意味的関係の判断に必要な単 語間に限定して類似度を計算し，その平均を特徵量としている。そのため，公理の確信度は概 念間の距離 - 同義語の一致率よりも効率的な特徵量として, 含意関係の予測性能に寄与したと 考えられる。

\section{4 正解ラベル別の評価}

\subsection{1 文間類似度学習}

SICK データセットにおける, 正解スコア別の類似度学習の評価結果を表 10 に示す。この結 果から, 提案手法は $4 \leq x<5$ の範囲の類似度スコアが付与されている文ぺアにおいて最も精 度が高いことが確認された，実際に， $4 \leq x<5$ の範囲の類似度スコアが付与されている文ペア の 8 割が含意か矛盾の関係にある文ペアであり，提案手法は特に論理的関係がある文ぺアにお いて高精度で類似度を予測することが示唆された。

表 10 正解スコア別の類似度学習の評価結果 (SICK)

\begin{tabular}{c|c|c|c|c}
\hline 正解スコア & データ数 & $\gamma$ & $\rho$ & $\mathrm{MSE}$ \\
\hline $1 \leq x<2$ & 300 & 0.4631 & 0.4522 & 0.7203 \\
$2 \leq x<3$ & 800 & 0.2829 & 0.2849 & 0.3980 \\
$3 \leq x<4$ & 2,000 & 0.2280 & 0.2104 & 0.2028 \\
$4 \leq x<5$ & 1,654 & 0.6185 & 0.6408 & 0.2673 \\
\hline All & 4927 & 0.8420 & 0.7988 & 0.2290 \\
\hline
\end{tabular}




\subsection{2 含意関係認識}

次に, SICK データセットにおける, 正解ラベル別の含意関係認識の評価結果を表 11 に示す. なお，ここでは yes, no, unknownの 3 值分類におけるすべてのラベルに関してスコアを算出し, その重み付け平均によって算出した適合率, 再現率, F1 值を評価指標に用いた。 この結果から, 提案手法は特に文間の矛盾関係の判定において高精度を発揮することが確かめられた. SICK データセットにおいて，矛盾関係にある文ぺアの多くは否定表現を含んでいることから，この 結果は，提案手法が論理推論を用いて否定表現を含む文の意味を正確に捉えていることを示唆 している.

\section{5 本研究の手法と深層学習による手法との比較}

SICK テストデータ 4,927 件の文例に対して, 提案手法の推論由来の特徵量のみを用いて学習 したモデルによる予測類似度と, 本タスクで最高精度を達成した深層学習のモデル (Mueller and Thyagarajan 2016) による予測類似度との比較を行った。 その結果, 4,927 件中 2,666 件は提案 手法の方が正解スコアに近い類似度を予測していた。 さらに，この 2666 件について，特にどの ような言語現象を含む文例において推論由来の特徵量が有用であるか, 傾向を分析した.テス トデータ全体に含まれる否定・量化・等位接続・関係代名詞を含む文例数をそれぞれカウント した結果を表 12 に示す.

また,これらの文例のうち，提案手法が高精度で予測した文例数とテストデータ中の割合を 計算した結果を表 13 に示す。表から, 推論由来の特徵量は否定表現や量化表現, 等位接続を含

表 11 各正解ラベルの含意関係認識の評価結果 (SICK)

\begin{tabular}{l|c|c|c|c}
\hline 正解ラベル & データ数 & 適合率 & 再現率 & F1 值 \\
\hline Unknown & 2,793 & 0.8597 & 0.9391 & 0.8977 \\
No & 720 & 0.9476 & 0.8075 & 0.8720 \\
Yes & 1,414 & 0.8855 & 0.7918 & 0.8360 \\
All & 4,927 & 0.8801 & 0.8774 & 0.8761 \\
\hline
\end{tabular}

表 12 言語現象の例

\begin{tabular}{l|c|l|l}
\hline \multicolumn{1}{c|}{$\overline{\overline{1}}$ 語現象 } & 件数 & \multicolumn{1}{|c|}{ 対象の単語 } & \multicolumn{1}{c}{ 文例 } \\
\hline 否定 & 544 & no, not (n't), nobody & $\begin{array}{l}\text { There is no man in a black jacket doing tricks on a motorbike } \\
\text { A person in a black jacket is doing tricks on a motorbike }\end{array}$ \\
\hline 量化 & 720 & $\begin{array}{l}\text { many, few, some, } \\
\text { any, all, every, 数詞 }\end{array}$ & $\begin{array}{l}\text { Some cheerleaders are dancing } \\
\text { A female cheerleader is sitting on the knee of a male cheerleader }\end{array}$ \\
\hline 等位接続 & 1,044 & and, or & $\begin{array}{l}\text { A man and a woman are walking through the woods } \\
\text { The man and woman are walking }\end{array}$ \\
\hline 関係代名詞 & 158 & $\begin{array}{l}\text { what, which, who, } \\
\text { when, where, how }\end{array}$ & $\begin{array}{l}\text { A small child is showing excitement on a swing set at the park } \\
\text { The girl is standing behind the little woman who is swinging }\end{array}$ \\
\hline
\end{tabular}


む文例において，深層学習のモデルよりも高精度で類似度を予測する傾向が示唆された。

\section{6 エラー分析}

最後に, 推論由来の特徵量のみで学習したモデルで予測したスコアが正解スコアと 1.5 以上 離れていた文例 119 件について，エラー分析を行ったＳICK データセットの類似度・含意関係 の評価結果のエラー分析の例を表 14 に示す.

1264 では, 各文中の onstage と on a stageをどちらも副詞として捉えるのが正しい統語解析 結果であるが, 統語解析のエラーによって onstage が perform の目的語として捉えられてしま い, 統語解析の結果に従って誤った論理式に変換されたため，含意関係を証明できず，予測ス コアが正解スコアよりも低くなってしまった例である。このような例では 2 文間の統語解析の 結果の整合性を考慮するなど, 統語解析の改善が必要である。6637では, 1 文目の leap over を 1 つ動詞のイディオムとして論理式に変換する必要があるが, 変換に失敗し, 予測スコアが正 解スコアよりも低くなってしまった例である。このような例では，イデイオムに関する外部知 識を参照して論理式に変換するといった改善策が考えられる，2831 は含意関係がある文ぺアで あるが, penciling on eyeshadowと using an eye pencil on her eyelid 間の公理を生成できなかっ たため含意関係を証明できず，予測スコアが正解スコアよりも低くなってしまった例である。

表 13 言語現象ごとの分析結果

\begin{tabular}{l|r|c|l}
\hline 言語現象 & 件数 & テストデータ中の割合 & \multicolumn{1}{c}{ 文例 } \\
\hline 否定 & 308 & $57 \%$ & $\begin{array}{l}\text { Nobody is playing ping pong } \\
\text { Two people are playing ping pong }\end{array}$ \\
\hline 量化 & 409 & $57 \%$ & $\begin{array}{l}\text { A few men in a competition are running outside } \\
\text { The man is racing for the lead }\end{array}$ \\
\hline 等位接続 & 625 & $60 \%$ & $\begin{array}{l}\text { The woman is not wearing glasses or a headdress } \\
\text { The woman is wearing glasses and a black headdress }\end{array}$ \\
\hline 関係代名詞 & 80 & $51 \%$ & $\begin{array}{l}\text { A dog, which is brown, and a black one are racing in the grass } \\
\text { A dark black dog and a light brown dog are playing in the backyard }\end{array}$ \\
\hline
\end{tabular}

表 14 エラー分析

\begin{tabular}{|c|c|c|c|c|c|c|}
\hline \multirow{2}{*}{ ID } & \multirow{2}{*}{ 文ペア } & \multicolumn{2}{|c|}{ 類似度 } & \multicolumn{2}{|c|}{ RTE } & \multirow{2}{*}{$A \Rightarrow B$ の証明で生成した公理 } \\
\hline & & 正解 & 予測 & 正解 & 予測 & \\
\hline 1264 & $\begin{array}{l}\text { A band is performing onstage } \\
\mathrm{A} \text { band is performing on a stage }\end{array}$ & 5.0 & 3.4 & yes & unk & \\
\hline 6637 & $\begin{array}{l}\text { A horse and its rider are not leaping over a barrier } \\
\text { A horse is leaping a hurdle and has a rider on its back }\end{array}$ & 4.6 & 2.9 & no & unk & \\
\hline 2831 & $\begin{array}{l}\text { The lady is penciling on eyeshadow } \\
\text { The girl is using an eye pencil on her eyelid }\end{array}$ & 4.4 & 2.7 & yes & unk & $\forall x(\operatorname{pencil}(x))$ \\
\hline 1941 & $\begin{array}{l}\text { A woman is putting the baby into a trash can } \\
\text { A person is putting meat into a skillet }\end{array}$ & 1.0 & 3.3 & unk & yes & $\begin{array}{l}\forall x(\operatorname{woman}(x) \rightarrow \operatorname{person}(x)) \\
\forall x(\operatorname{trash}(x) \rightarrow \operatorname{skillet}(x)) \\
\forall x(\operatorname{baby}(x) \rightarrow \operatorname{meat}(x))\end{array}$ \\
\hline
\end{tabular}


このような例では，フレーズ間の関係知識を用いて公理を生成する必要がある。1941 は含意関 係のない文ぺアであるが，公理の過剰生成によって含意関係を証明できてしまい，予測スコア が正解スコアよりも高くなってしまった例である。本研究では公理の確信度に単語間類似度を 採用し，確信度が閾值以上である場合のみに公理を採用しているが，このような公理の過剰生 成を防ぐためには，文脈に合わせて正しく公理の確信度を算出するよう改善する必要がある。

\section{5 まとめ}

本研究では，文を高階述語論理式に変換し，文間の含意関係を高階論理の推論によって判定 するシステムの実行過程に関する情報から, 文間の関連性に寄与する特徵を抽出し, 文間の関連 性を学習する手法を提案した。文間類似度学習と含意関係認識という 2 つの自然言語処理夕ス クに関して複数のデータセットを用いて評価を行った結果, 推論の過程を特徴量として組み合 わせることによって，いずれのタスクにおいても精度が向上した。 また，含意関係認識用デー タセットの一つである SICK データセットの評価では最高精度を達成した。 今後の展望として は, 統語解析, 意味合成, 論理推論のそれぞれのフェーズにおいて改善策を検討していく. 統 語解析においては，文ぺア間で統語解析結果が異なるために証明に失敗した例が数件見られた ため，文ぺア中に同じ動詞が含まれていれば，各文の動詞に同じ統語範疇を優先して割り当て るといった改善策が挙げられる。意味合成においては，統語解析の結果に加えて外部知識を利 用することで，イデイオムなどを含む文についても適切な論理式に変換するといった改善策が 挙げられる。論理推論においては, フレーズ間の公理の生成方法の検討, 公理の確信度の計算 方法の改善などが今後の課題として挙げられる。また，本稿では含意関係認識と文間類似度学 習のタスクにおいて提案手法の評価を行ったが, 今後, 質問応答など他の自然言語処理タスク への適用が期待される。

\section{謝 辞}

本研究は, JST 戦略的創造研究推進事業 CREST (JPMJCR1301) およびAIP チャレンジの 支援を受けて行われた。また，本研究の一部は, the 2017 Conference on Empirical Methods in Natural Language Processing (EMNLP2017) で発表したものである (Yanaka, Mineshima, Martínez-Gómez and Bekki, 2017) . 


\section{参考文献}

Abzianidze, L. (2015). "A Tableau Prover for Natural Logic and Language." In Proceedings of the 2015 Conference on Empirical Methods in Natural Language Processing (EMNLP-2015), pp. 2492-2502.

Abzianidze, L. (2016). "Natural Solution to FraCaS Entailment Problems." In Proceedings of the 5th Joint Conference on Lexical and Computational Semantics, pp. 64-74.

Agirre, E., Cer, D., Diab, M., and Gonzalez-Agirre, A. (2012). "SemEval-2012 Task 6: A Pilot on Semantic Textual Similarity." In Proceedings of the 6th International Workshop on Semantic Evaluation (SemEval-2012), pp. 385-393.

Bär, D., Biemann, C., Gurevych, I., and Zesch, T. (2012). "UKP: Computing Semantic Textual Similarity by Combining Multiple Content Similarity Measures." In Proceedings of the 6th International Workshop on Semantic Evaluation (SemEval-2012), pp. 435-440.

Bekki, D. and Mineshima, K. (2017). "Context-Passing and Underspecification in Dependent Type Semantics." In Chatzikyriakidis, S. and Luo, Z. (Eds.), Modern Perspectives in Type Theoretical Semantics, Studies of Linguistics and Philosophy, pp. 11-41. Springer.

Beltagy, I., Roller, S., Boleda, G., Erk, K., and Mooney, R. (2014). "UTexas: Natural Language Semantics using Distributional Semantics and Probabilistic Logic." In Proceedings of the 8th International Workshop on Semantic Evaluation (SemEval-2014), pp. 796-801.

Bertot, Y. and Castran, P. (2010). Interactive Theorem Proving and Program Development: Coq'Art The Calculus of Inductive Constructions. Springer, New York, USA.

Bjerva, J., Bos, J., van der Goot, R., and Nissim, M. (2014). "The Meaning Factory: Formal Semantics for Recognizing Textual Entailment and Determining Semantic Similarity." In Proceedings of the 8th International Workshop on Semantic Evaluation (SemEval-2014), pp. 642-646.

Blei, D. M., Ng, A. Y., and Jordan, M. I. (2003). "Latent Dirichlet Allocation." Journal of Machine Learning, 3, pp. 993-1022.

Champollion, L. (2015). "The Interaction of Compositional Semantics and Event Semantics." Linguistics and Philosophy, 38 (1), pp. 31-66.

Clark, S., Coecke, B., and Sadrzadeh, M. (2011). "Mathematical Foundations for a Compositional Distributed Model of Meaning." Linguistic Analysis, 36 (1-4), pp. 345-384.

Clark, S. and Curran, J. R. (2007). "Wide-coverage Efficient Statistical Parsing with CCG and Log-linear Models." Computational Linguistics, 33 (4), pp. 493-552.

Curran, J. R. and Clark, S. (2003). "Investigating GIS and Smoothing for Maximum Entropy 
Taggers." In Proceedings of the 10th Conference on European Chapter of the Association for Computational Linguistics (EACL-2003), pp. 91-98.

Davidson, D. (1967). "The Logical Form of Action Sentences." In Rescher, N. (Ed.), The Logic of Decision and Action, pp. 81-95. University of Pittsburgh Press, Pittsburgh, PA. Reprinted in (Davidson 1980), pp. 105-148.

Davidson, D. (1980). Essays on Actions and Events. Clarendon Press, Oxford.

Deerwester, S., Dumais, S. T., Landauer, T. K., and Harshman, R. (1990). "Indexing by Latent Semantic Analysis." Journal of the American Society for Information Science, 41 (6), pp. 391-407.

Grefenstette, E. and Sadrzadeh, M. (2011). "Experimental Support for a Categorical Compositional Distributional Model of Meaning." In Proceedings of the 2011 Conference on Empirical Methods in Natural Language Processing (EMNLP-2011), pp. 1394-1404.

He, H. and Lin, J. (2016). "Pairwise Word Interaction Modeling with Deep Neural Networks for Semantic Similarity Measurement." In Proceedings of the 2016 Conference of the North American Chapter of the Association for Computational Linguistics: Human Language Technologies (NAACL/HLT-2016), pp. 937-948.

Hill, F., Cho, K., and Korhonen, A. (2016). "Learning Distributed Representations of Sentences from Unlabelled Data." In Proceedings of the 2016 Conference of the North American Chapter of the Association for Computational Linguistics: Human Language Technologies (NAACL/HLT-2016), pp. 1367-1377.

Hockenmaier, J. and Steedman, M. (2007). "CCGbank: A Corpus of CCG Derivations and Dependency Structures Extracted from the Penn Treebank." Computational Linguistics, $\mathbf{3 3}$ (3), pp. 355-396.

Kartsaklis, D., Kalchbrenner, N., and Sadrzadeh, M. (2014). "Resolving Lexical Ambiguity in Tensor Regression Models of Meaning." In Proceedings of the 52nd Annual Meeting of the Association for Computational Linguistics (ACL-2014), pp. 212-217.

Kartsaklis, D. and Sadrzadeh, M. (2016). "Distributional Inclusion Hypothesis for Tensor-based Composition." In Proceedings of the 26th International Conference on Computational Linguistics: Technical Papers (COLING-2016), pp. 2849-2860.

Le, Q. V. and Mikolov, T. (2014). "Distributed Representations of Sentences and Documents." In Proceedings of the 31th International Conference on Machine Learning, (ICML-2014), pp. $1188-1196$.

Lewis, M. and Steedman, M. (2014). "A* CCG Parsing with a Supertag-factored Model." In Proceedings of the 2014 Conference on Empirical Methods in Natural Language Processing 
(EMNLP-2014), pp. 990-1000.

Marelli, M., Menini, S., Baroni, M., Bentivogli, L., Bernardi, R., and Zamparelli, R. (2014). "A SICK Cure for The Evaluation of Compositional Distributional Semantic Models." In Proceedings of the 9th International Conference on Language Resources and Evaluation (LREC2014), pp. 216-223.

Martínez-Gómez, P., Mineshima, K., Miyao, Y., and Bekki, D. (2016). "ccg2lambda: A Compositional Semantics System." In Proceedings of ACL-2016 System Demonstrations, pp. 85-90.

Martínez-Gómez, P., Mineshima, K., Miyao, Y., and Bekki, D. (2017). "On-demand Injection of Lexical Knowledge for Recognising Textual Entailment." In Proceedings of the 15th Conference of the European Chapter of the Association for Computational Linguistics (EACL2017), pp. 710-720.

Martínez-Gómez, P. and Miyao, Y. (2016). "Rule Extraction for Tree-to-Tree Transducers by Cost Minimization." In Proceedings of the 2016 Conference on Empirical Methods in Natural Language Processing (EMNLP-2016), pp. 12-22.

Mikolov, T., Sutskever, I., Chen, K., Corrado, G. S., and Dean, J. (2013). "Distributed Representations of Words and Phrases and their Compositionality." In Burges, C. J. C., Bottou, L., Welling, M., Ghahramani, Z., and Weinberger, K. Q. (Eds.), Advances in Neural Information Processing Systems 26, pp. 3111-3119. Curran Associates, Inc.

Miller, G. A. (1995). "WordNet: A Lexical Database for English." Communications of the ACM, 38 (11), pp. 39-41.

Mineshima, K., Martínez-Gómez, P., Miyao, Y., and Bekki, D. (2015). "Higher-order Logical Inference with Compositional Semantics." In Proceedings of the 2015 Conference on Empirical Methods in Natural Language Processing (EMNLP-2015), pp. 2055-2061.

Mineshima, K., Tanaka, R., Martínez-Gómez, P., Miyao, Y., and Bekki, D. (2016). "Building Compositional Semantics and Higher-order Inference System for a Wide-coverage Japanese CCG parser." In Proceedings of the 2016 Conference on Empirical Methods in Natural Language Processing (EMNLP-2016), pp. 2236-2242.

Mitchell, J. and Lapata, M. (2008). "Vector-based Models of Semantic Composition." In Proceedings of the 46th Annual Meeting of the Association for Computational Linguistics (ACL2008), pp. 236-244.

Mitchell, J. and Lapata, M. (2010). "Composition in Distributional Models of Semantics." Cognitive Science, 34 (8), pp. 1388-1429.

Mueller, J. and Thyagarajan, A. (2016). "Siamese Recurrent Architectures for Learning Sentence Similarity." In Proceedings of the 30th AAAI Conference on Artificial Intelligence (AAAI- 
2016), pp. 2786-2792.

Parsons, T. (1990). Events in the Semantics of English: A Study in Subatomic Semantics. MIT Press, Cambridge, USA.

Peter, W. C. and Wilkins, W. K. (1984). Locality in Linguistic Theory. Academic Press, Florida, USA.

Prawitz, D. (1965). Natural Deduction-A Proof-Theoretical Study. Almqvist \& Wiksell, Stockholm, Sweden.

Ray, J. (1990). Semantic Structures. MIT Press, Cambridge, USA.

Steedman, M. (2000). The Syntactic Process. MIT Press, Cambridge, USA.

Tai, K. S., Socher, R., and Manning, C. D. (2015). "Improved Semantic Representations From Tree-Structured Long Short-Term Memory Networks." In Proceedings of the 53rd Annual Meeting of the Association for Computational Linguistics and the 7th International Joint Conference on Natural Language Processing (ACL/IJCNLP-2015), pp. 1556-1566.

Wong, S. K. M. and Raghavan, V. V. (1984). "Vector Space Model of Information Retrieval: A Reevaluation." In Proceedings of the 7th Annual International ACM SIGIR Conference on Research and Development in Information Retrieval, pp. 167-185.

Yin, W. and Schütze, H. (2017). "Task-Specific Attentive Pooling of Phrase Alignments Contributes to Sentence Matching." In Proceedings of the 15th Conference of the European Chapter of the Association for Computational Linguistics (EACL-2017), pp. 699-709.

Yoshikawa, M., Noji, H., and Matsumoto, Y. (2017). "A* CCG Parsing with a Supertag and Dependency Factored Model." In Proceedings of the 55nd Annual Meeting of the Association for Computational Linguistics (ACL-2017), pp. 277-287.

Zhou, Y., Liu, C., and Pan, Y. (2016). "Modelling Sentence Pairs with Tree-structured Attentive Encoder." In Proceedings of the 26th International Conference on Computational Linguistics (COLING-2016), pp. 2912-2922.

\section{略歴}

谷中 瞳 : 1989 年生. 2011 年早稲田大学先進理工学部応用化学科卒業. 2013 年東京大学大学院工学系研究科科学システム工学専攻修士課程修了。同年, 株式会社野村総合研究所入社後, 2015 年東京大学大学院工学系研究科システ 厶創成学専攻博士課程進学.

峯島 宏次： 2013 年慶應義塾大学文学研究科博士課程修了。博士（哲学）。現 在，お茶の水女子大学シミュレーション科学・生命情報学教育研究センター 特任准教授. 
Pascual Martínez-Gómez: received his Ph.D. degree in Computer Science at the University of Tokyo in 2014 for his research on eye-tracking and readability diagnosis. He is a research scientist at the Artificial Intelligence Research Center in the National Institute of Advanced Industrial Science and Technology (AIST), Japan.

戸次 大介：2000 年東京大学大学院理学系研究科情報科学専攻博士課程修了. 博士 (理学). 現在, 矤茶の水女子大学基幹研究院自然科学系准教授.

$(2017$ 年 10 月 15 日 受付 $)$
$(2018$ 年 1 月 17 日 再受付 $)$
$(2018$ 年 3 月 6 日 採録 $)$

